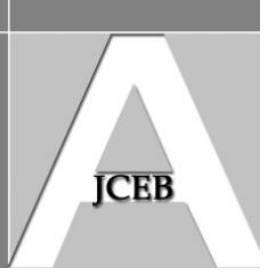

\title{
International Projects and Cross-Cultural Adjustment of British Expatriates in Middle East: A Qualitative Investigation of Influencing Factors
}

\author{
Ashwini Konanahalli, Lukumon Oyedele, Jason von Meding, John Spillane \\ and Ron Coates (Queen's University Belfast, United Kingdom)
}

\begin{abstract}
Increased globalisation within the British AEC (Architectural, Engineering and Construction) sector has increased the need for companies to transfer staff to manage their overseas operations. To be able to perform abroad, expatriates must harmonise themselves to the conditions prevailing in the host country. These include getting accustomed to living, working and interacting with the host country nationals. The process is commonly referred to as 'cross-cultural adjustment'. Various factors influence the process of adjustment. In order to identify these issues, a qualitative study was undertaken, which mainly comprised of comprehensive literature review, individual interviews and focus group discussion with British expatriates working on international AEC assignments in Middle Eastern countries. Through interpretative approach, the current study aims to understand the concept of crosscultural adjustment of British Expatriates based in Middle East and their influencing factors.
\end{abstract}

The findings suggest that success of expatriation does not entirely rest on an expatriate's ability but also on organisational support and assistance that expatriates receive prior to and during the assignment. Organisational factors such as selection mechanisms, job design, training, logistical and social support, mentoring, etc., influence various facets of expatriate adjustment. Striking cultural contrasts between British and Arab culture both in work and non work situations also dictate the level of support required by the expatriate, suggesting that relocation to less developed, remote or politically unstable regions, demands additional support and consideration by the parent company. This study is relevant to the AEC companies employing British expatriates, who need to be cognisant of the issues highlighted above to make rational and informed decisions when handling international assignments in the Middle East.

Keywords: Cross-cultural adjustment, International Project Management, Middle East and North Africa, Organisational strategies, Overseas AEC Assignments, Work related factors

\section{Introduction}

With the increase of business globalisation, international mobility is becoming a common experience for a growing number of employees sent on long term-assignments (Hechanova et al., 2003). The international AEC (Architectural, Engineering and Construction) sector is no exception. The basic nature of the construction operations, along with the growing demand from emerging economies, has lead to many international AEC firms expatriating constructional professionals, such as architects, consultants, managers, contractors, etc., across various units, to transfer technology (Carrillo, 1994) and manage overseas operations. Achieving success on these assignments is an essential issue for such companies, as it is indispensible for developmental, functional and reputational reasons (Dowling et al., 1998; Strohl and Caliguiri, 1998; Black et al., 1991; Tung and Miller, 1990).

Recent studies suggest that international organisations are increasingly struggling to manage their personnel on international assignments, particularly as it relates to assisting expatriates and their families to stay until completion of the assignment and then retaining 
them for future postings (GMAC, 2008). Expatriation is very expensive due to associated high cost of sending and maintaining personnel overseas (Hechanova et al., 2003). As a result, one of the major challenges faced by the international organisations is how to effectively use their expatriates to deliver their overseas assignments (Chi and Levitt, 2009). The expectation placed on an expatriate will be to perform the same set of functions that they will normally do on the domestic front but in a totally different and complex environment (Yamazaki and Kayes, 2005).

However, the expatriate will be challenged with differences in cultural norms, regulations, routines, work cultures, institutional work practices, safety standards, etc., which can manifest themselves as added costs, delays and conflicts on these assignments (Chua et al., 2003; Miller \& Lessard, 2001 and Orr, 2005). Grove, (1990) and Fish, (2005) appropriately suggest that expatriates need to possess the ability to deal effectively with frustration, stress, different political systems, interaction with strangers, intercultural and business dimensions.

In all these aforementioned cases, cross-cultural adjustment of these personnel, posted on international assignments, therefore becomes an important issue. Adjustment is defined as a state where variations or modifications become apparent in an individual to accommodate environmental demands (Berry, 1992). An expatriate has to adjust to three specific aspects namely, general environment, interaction with host country nationals and work (Black \& Stephens, 1989). Cross-cultural adjustment is the primary outcome of the international assignment on the expatriate, it further influences the sense of achievement in terms of satisfaction, performance and assignment completion (SriRamalu, et al., 2010). Studies into international adjustment by Black and his associates conceptualised it as a multidimensional concept suggesting that different antecedents may have different impacts on each of its facets (Black, et al., 1991). Adjustment is also one of the most frequently studied factors in assessing the success of an international assignment (Aycan and Kanungo, 1997, Ones and Viswesvaran, 1997).

Despite intensive studies on cross-cultural adjustment in business management sectors, similar research within the realm of International AEC industry, appears to be lacking (except for Puck, et al., 2008; Zainol \& Abdul Aziz, 2010), even though internationalisation is not a new concept to this field - it has been in existence before the 20th century (Pheng and Leong, 2000) - and that the British construction industry has the longest history in international construction operations (Crosthwaithe, 1998). During the 1970's the booming oil price (Ngowi, 2005) coupled with shortage of local skills, technology and resources, made way for intervention by international AEC firms from US and European countries (Loosemoore and Muslmani, 1999). As a result, British based AEC firms continue to have significant presence in these oil rich Middle Eastern regions.

This paper is based on a literature review and the viewpoints of AEC industry representatives. It seeks to understand the adjustment process of British expatriates working within international AEC firms including architectural consultants, engineering consultants, contractors, project managers, etc. British expatriates (BEs) in this context are defined as a British nationals sent by their parent companies to manage international assignments on projects for a certain time period lasting from several months to years (Edstrom and Galbraith, 1977). This study will only concentrate on exploring the impact of organisational, work and non-work parameters on cross-cultural adjustment.

\section{Methodology}

This paper is specifically designed to explore a sub-set of variable of British expatriates' cross-cultural adjustment in the Middle-Eastern region. Of interest are Middle East countries which are mostly of Arab culture and seen as very different from Western culture. These

Konanahalli A et al. (2012) 'International projects and cross-cultural adjustments of British expatriates in Middle East: A qualitative investigation of influencing factors', Australasian Journal of Construction Economics and Building, 12 (3) $31-54$ 
countries include; Algeria, Bahrain, Egypt, Iran, Iraq, Israel, Jordan, Kuwait, Lebanon, Libya, Morocco, Oman, Qatar, Saudi Arabia, Syria, Tunisia, United Arab Emirates, West Bank, Gaza and the Yemen.

To explore the phenomenon of adjustment in a sample of British expatriate's, this study adopted two approaches, namely,

- Literature review and,

- Qualitative research

Due to the broad scope of this topic, the literature review has been a critical aspect of the research. Factors influencing cross-cultural adjustment have been sparsely explored in the international Architectural, Engineering and Construction (AEC) sector. To understand the work, non-work and organisational antecedents of adjustment, this research probed deep into the literature by reviewing it with reference to studies conducted in various sectors of business management, psychology and international human resource management.

Additionally, the researchers adopted a qualitative methodology to understand the concept of expatriate's cross-cultural adjustment from the participant's perspective, primarily to avoid losing social and institutional context during quantification of textual data (Kaplan and Maxwell, 1994). The researchers conducted a systematic enquiry, attempting to interpret and make sense of the phenomena and the meanings that individuals attribute to them (Shank, 2002). A qualitative approach was considered appropriate for the following reasons;

- to examine complex issues of causality, process and context (Dudwick, et al., 2006);

- to explore the main actor's interpretation of events and to draw conclusions from them;

- and most importantly, to first identify the variables that might later be tested quantitatively (Hoepfl, 1997).

Hence, qualitative research is considered to be apt as opposed to quantitative research. Qualitative research methods include, interviewing, archival research and participant observation (Myers and Avison, 2002). This study adopted interviewing, since it aimed to gain a deeper understanding of Middle Eastern culture and societies. Furthermore, the researchers used individual interviews and focus group discussions, the two most common methods to collect qualitative data (Gill et al.,2008). Other qualitative techniques like, archival research and participant observation were ruled out, as most expatriates were based overseas and there was no scope to observe them in action and no access to written records.

\section{Literature Review}

\section{Cross-cultural Adjustment}

Cross-cultural adjustment is referred to as the degree to which an expatriate is psychologically comfortable with various aspects of the foreign country (Black, 1988). It involves uncertainty reduction by imitating or learning appropriate local behaviours and harmonising with the culture (Peltokorpi and Froese, 2009).

An expatriate needs to adjust his/her behaviour to the norms and rules of the host nation. Failure to adjust will result in early return prior to assignment completion (Harzing, 1995), poor job performance and low levels of satisfaction (Naumann, 1993). On the other hand, successful adjustment will result in integration of some elements of expatriate original culture with that of the host country (Kim and Ruben, 1988). As a result well adjusted expatriates are able to perform effectively. Black and Stephens, (1989); Black, (1988) and Black et al., (1991) identified three aspects of adjustment. Each is briefly discussed below.

Konanahalli A et al. (2012) 'International projects and cross-cultural adjustments of British expatriates in Middle East: A qualitative investigation of influencing factors', Australasian Journal of Construction Economics and Building, 12 (3) $31-54$ 


\section{Interaction Adjustment}

This aspect deals with the comfort levels when dealing or interacting with host country nationals at work and in non-work situations (Black and Stephens 1989). It is also suggested that interaction is the most difficult of the three facets of adjustment.

\section{Work Adjustment}

This involves adapting oneself to the new job tasks, roles and environment. Work adjustment is easier if there are similarities between the parent and the host subsidiary in terms of procedures, policies and task requirements (Black and Stephens 1989).

\section{General Adjustment}

This second facet deals with overall adjustment to living in a foreign land and adjusting to its culture (Black, 1988). It comprises factors such as housing conditions, healthcare, cost of living, etc. (Black and Stephens 1989).

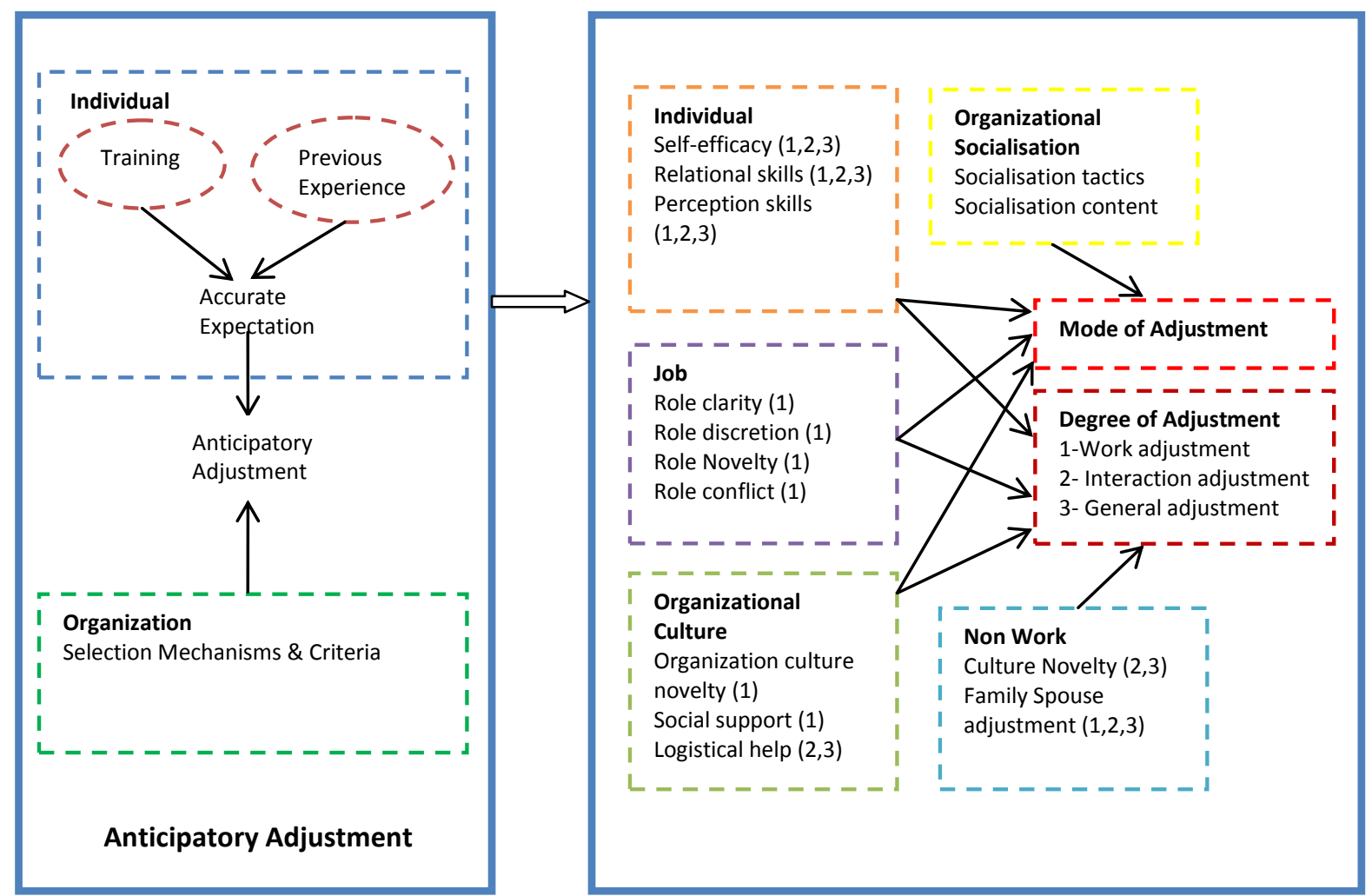

Figure 1 Frame-work for Cross-cultural Adjustment by Black et al. (1991)

\section{Antecedents of Cross-cultural Adjustment}

Recent studies on adjustment have conceptualised it as a multi-faceted phenomenon with three major dimensions (Black 1988, Black and Gregersen, 1991, Black et al., 1991, McEvoy and Parker 1995) all of which have been empirically tested. Adopting a multiple theoretical perspective Black et al., (1991) have identified a host of factors that influence all three facets of adjustment and phased these factors into pre-assignment and in-country periods (Refer to Figure 1). Since the aim of this study is to investigate organisational, non-work and work determinants of expatriate adjustment, the individual factors have not been discussed.

\section{Anticipatory Adjustment}

Anticipatory adjustment is the input from domestic adjustment literature. According to Black et al., (1991) adjustment will be a lot easier and quicker, if anticipatory adjustment has been worked out well. The two aspects to be dealt with during this period include expatriate selection and providing cross-cultural training.

Konanahalli A et al. (2012) 'International projects and cross-cultural adjustments of British expatriates in Middle East: A qualitative investigation of influencing factors', Australasian Journal of Construction Economics and Building, 12 (3) $31-54$ 


\section{Organisational Factors}

\section{- Expatriate Selection}

During the anticipatory phase, when considering individuals for foreign assignments, the most important organisational factors to be considered are the criteria and the process of expatriate selection (Black et al., 1991). This has been substantiated by researchers, who have long been advocating effective recruitment and selection systems for successful expat assignments (Tung, 1981, 1982). In spite of this, to date, most organisations continue to rely on technical skills and domestic track record as the criteria for selection (Morley and Flynn, 2003; Sparrow et al., 2004).

\section{- Cross-cultural Training}

Cross-cultural training is an intervention to escalate an individual's aptitude to deal with and perform in an unfamiliar environment (Tung, 1981). Studies by Mendenhall and Oddou, (1985); Tung, (1981); Mendenhall et al., (1987); Black and Mendenhall, (1990) suggest that comprehensive cross-cultural training is helpful in building an expatriate's cross-cultural skills and competencies. Trained expatriates are able to carry themselves confidently and work efficiently with less supervision (Gutterridge et al., 1993) and have the potential to predict success on international projects (Parkinson and Morley, 2006).

\section{In-Country Adjustment}

The literature for integration of domestic and international adjustment with respect to Incountry adjustment is more complicated than the anticipatory phase (Black et al., 1991), the reason being that it requires both mode and degree of adjustment. In-Country adjustment comprises of job, organisational culture and non-work factors.

\section{- Job factors}

Job factors are definite sets of tasks and duties performed by the expatriates (Selmer and Fenner, 2009). Therefore they are categorised into two groups (Black, 1988);

- Adjustment facilitating job factors

- Adjustment inhibiting job factors

Role clarity and role discretion are two job related factors that facilitate work adjustment (Black et al., 1991). Expatriates whose job roles, responsibilities and behaviours to be undertaken, are set up clearly by the organisation (Andreason, 2003; Bhaskar-Shrinivas et al, 2005), experience less uncertainty associated with their work situation and in turn adjust to their work quickly (Black 1988, Nicholson, 1984, and Pinder and Schroeder 1987). Similarly, flexibility in the working environment (role discretion) allows the expatriate to mould the job to his or her expectations.

There are several job-related factors that could increase the uncertainties, unfamiliarity's, unpredictability or uncontrollability of the new role and consequently inhibit adjustment (Black et al., 1991). Novel work settings could vary from the home nation demanding new skill sets and behaviours, which means the expatriate has a tremendous amount of information to process like, legal, economic, political, taxation and also how to interact with locals (Andreason, 2003).

On the other hand, when an expatriate experiences conflict; ambiguity between the expectations held regarding job behaviours, duties, do's and don'ts, uncertainty levels are likely to increase and so impede adjustment. Also, placing excessive demands on expatriates who assume new positions (Brewster and Harris, 1999) i.e. role overload is likely to produce similar consequences. 


\section{- Organizational factors}

Organisational factors include organisation cultural novelty, social and logistical support provided by the organisation. Black et al., (1991) propose organisational cultural novelty would be expected to increase the uncertainty associated with work environment (Church, 1982; Mendenhall \& Oddou, 1985 and Stening, 1979). The greater the difference between the parent organisation and the host country subsidiary, the greater are the adjustment challenges (Black et al., 1991).

An expatriate's relocation to an unfamiliar environment is a stressful event. Organisational support on the logistic front is essential; it helps to reduce the amount of time they spend on these issues and facilitates adjustment to the new work set-up (Aycan, 1997). It includes sorting out visas, work permits, housing, organising school for their children, medical insurance, etc.

Social support mainly assists in mobilising psychological resources and further provides feelings of reinforcement, recognition and affirmation (Fontaine, 1986; Rook, 1984). This support could stem from family, host national colleagues, compatriots, or in some instances expatriates from other countries. Particularly on the work front, expatriates should be provided with clear information on the do's and the don'ts especially if the organisational culture novelty between the home and the host country subsidiary is high. Studies suggest that social support has a positive impact on their ability to adapt to the new environment (Coyle, 1992 and Brewster and Scullion, 1997).

\section{- Non work factors}

Factors listed under this section include culture novelty of the host country and familyspouse adjustment.

Cultural distance refers to the extent of cultural differences between the home and the host country (Shenkar, 2001). It is also referred to as "Cultural toughness" or "Cultural novelty". Church (1982), Mendenhall \& Oddou (1985) and Stening (1979) argue that cultural novelty of the host country increases uncertainty i.e. perceived discrepancies between the home and host countries increase the level of doubts and present the expatriates with adjustment difficulties.

Adjustment of the spouse and family are important because a child's maladjustment to various aspects of the host nation adversely affects the sojourner's own adjustment thereby affecting their work performance (Earley and Ang, 2003). Prior research has substantiated that the inability of the spouses/family to adjust to living in the host country was one of the most frequently cited reasons for failure among American expatriates (Black and Stephens, 1989; Harvey 1985 and Tung 1981). Ever changing work place demographics suggests that organisations need to take into consideration dual career couples when thinking of relocation (Selmer and Leung, 2003). Therefore organisations should tune resources in this direction, as it enhances both the expatriate's and his/her partner's satisfaction with foreign assignment.

\section{Other Organisational Issues}

\section{Free Choice for Accepting International Assignments}

Free choice refers to the degree to which an individual can choose to accept the assignment (Cerdin \& Pargneux, 2009). It helps to judge whether the assignment fits well with their will, skills and knowledge (Chenyi \& Baruch, 2010). Expatriates lacking free choice or being pressurised by organisations to take up assignments against their will would not only face adjustment difficulties but also develop negative attitudes towards the job itself (Black \& Stephens, 1989). Studies by Feldman, (1988); Wanous, (1980); Hall, (1976) have established free choice as a necessary factor influencing success involving international

Konanahalli A et al. (2012) 'International projects and cross-cultural adjustments of British expatriates in Middle East: A qualitative investigation of influencing factors', Australasian Journal of Construction Economics and Building, 12 (3) $31-54$ 
transfers; Kraimer and Wayne (2004) found a positive relationship between free choice and adjustment.

\section{Mentoring}

An additional aspect of social support will be the appointment of a mentor, an individual who provides assistance on learning and understanding the culture of the assigned country (Volard et al., 1988). A mentor acts as the link between the head office and the expat, giving $\mathrm{him} /$ her information on the latest events and involving them in the decision making process (McCauhey and Bruning, 2005). Host nationals can also be mentors helping the expatriate gain concrete training in cultural behavior, introducing them to valued business contacts and provide assistance in interpreting situations (Kraimer et al., 2001). Mentoring helps to reduce any uncertainty associated with the new environment and make the expatriate feel more comfortable with their new work group and help them get more easily assimilated into the host culture (Caligiuri and Lazarova, 2002). Hence, mentored expats will not only adjust to work quickly but also interact efficiently with locals.

\section{Training Host Country Nations}

When operating overseas, an expatriate will certainly have to deal with local staff. To maintain output quality, an effective interaction with local staff is key. Vance and Pederon (1993) support the idea that the host nationals also need to be trained for assignments with foreigners. They advocate training as an ethical imperative for global firms as it assists in reducing stress and increasing the effectiveness of the individual. Such training will therefore facilitate greater work and interaction adjustment. In spite of this knowledge, expatriation research has not explored this dimension to its full detail (Vance and Ring, 1994).

\section{Ongoing Continuous Support}

An organisation needs to make a conscious effort to maintain contact between the expatriate and their head office. Ongoing assistance on technical or personal issues gives assurance to an employee that they are an integral part of the organisation, thus reducing anxiety and uncertainty associated with 'out of sight, out of mind' fears (Tung, 1988) and accelerates adjustment (Aycan, 1997).

\section{Qualitative Research}

\section{Data Collection}

The subject of the study involved British nationals managing or having previously managed, their parent organisation's international Architectural, Engineering and Construction (AEC) operations in Arab countries. Employing a random sampling technique a list of international British companies operating in Middle Eastern countries was obtained. Normally, researchers in the past have associated random sampling with quantitative research and non-random sampling with qualitative. As noted by Onwuegbuzie and Leech (2005) this represents a false dichotomy. It is suggested that both sampling techniques could be used either ways to increase options for researchers (Onwuegbuzie and Collins, 2007).

Telephone calls were made to British AEC companies and HR managers were contacted to seek approval for participation. Once approved, emails were sent out to the HR mangers reiterating the purpose and the confidentiality of the study. Only eight companies operating in seven Middle Eastern countries agreed to participate and provided access to their expatriates. Next, snowball sampling was used to secure additional participants. Snow ball sampling is used to elicit knowledge, from extended associations, through previous acquaintances (Babbie, 2008). This technique enables using recommendations to find more participants for the study. It is considered to be appropriate when targeting a special population (Babbie, 2008), in this case British expatriates. Respondents were contacted via e-mails and telephone calls. Upon agreement, in-depth individual interviews and focus group discussions were conducted.

Konanahalli A et al. (2012) 'International projects and cross-cultural adjustments of British expatriates in Middle East: A qualitative investigation of influencing factors', Australasian Journal of Construction Economics and Building, 12 (3) 31-54 


\section{Qualitative Individual Interviews}

Qualitative interviews are useful for understanding the background data and the evolution of the relationship between actor and the situation (Twum, 2010). To collect detailed information about an expatriate's experience of living and working overseas from their own perspective, unstructured in depth interviews were considered to be apt. This meant that the interviews had very little structure or preconceived plan as to how to deal with the topic (Hancock, 1998). During the unstructured interview the researchers asked open ended questions giving the respondent a chance to freely explain their opinion or experiences.

\begin{tabular}{|c|c|c|c|c|c|}
\hline $\begin{array}{l}\text { Interview } \\
\text { Code }\end{array}$ & $\begin{array}{c}\text { Assignment } \\
\text { duration in } \\
\text { years }\end{array}$ & $\begin{array}{l}\text { Industry } \\
\text { experience }\end{array}$ & $\begin{array}{l}\text { Job role during } \\
\text { the assignment }\end{array}$ & $\begin{array}{l}\text { Country of } \\
\text { Assignment }\end{array}$ & Profession \\
\hline UA-IN1 & Open & 15 & Project Architect & UAE & $\begin{array}{l}\text { Architectural } \\
\text { Consultants }\end{array}$ \\
\hline EG-IN2 & 2 & 21 & $\begin{array}{l}\text { Engineering } \\
\text { Consultant }\end{array}$ & Egypt & $\begin{array}{l}\text { Engineering } \\
\text { Consultancy }\end{array}$ \\
\hline UA-IN3 & 3 & 40 & $\begin{array}{l}\text { Business } \\
\text { development } \\
\text { director }\end{array}$ & UAE & $\begin{array}{l}\text { Architectural } \\
\text { Consultants }\end{array}$ \\
\hline BA-IN4 & Open & 30 & $\begin{array}{l}\text { Regional } \\
\text { Director }\end{array}$ & Bahrain & $\begin{array}{l}\text { Engineering } \\
\text { Consultancy }\end{array}$ \\
\hline UA-IN5 & 2 & 12 & Project Manager & UAE & $\begin{array}{c}\text { Architectural } \\
\text { Consultants }\end{array}$ \\
\hline OM-IN6 & 2.5 & 15 & $\begin{array}{l}\text { Health \& Safety } \\
\text { manager }\end{array}$ & Oman & Contractor \\
\hline KU-IN7 & 4 & 19 & Project Architect & Kuwait & $\begin{array}{l}\text { Architectural } \\
\text { Consultants }\end{array}$ \\
\hline KU-IN8 & 2 & 9 & $\begin{array}{l}\text { Quantity } \\
\text { Surveyor }\end{array}$ & Kuwait & $\begin{array}{l}\text { Architectural } \\
\text { Consultants }\end{array}$ \\
\hline
\end{tabular}

Table 1 Respondents profile for individual interviews

Overall eight individual interviews were carried out. Two were conducted in person, whereas the remaining six interviews had to be conducted using voice over IP technology because most expatriates were based overseas on assignments. However, no differences in the quality of the data could be observed between these two interviews types.

\section{Focus Group Discussions}

Apart from carrying out individual interviews, three focus group discussions (each group comprising of four expatriates) were also included. Focus group discussions involve individuals selected and assembled by the researcher to discuss and comment on the subject of the research from personal experience (Powell et. al., 1996). Based on the principle of data triangulation, the focus groups consisted of four expatriates from the same organisation. When individuals have specialized knowledge or experiences to discuss in the group, Krueger (1994) has endorsed the use of very small focus groups which include three (Morgan, 1997) or four participants. Since it is difficult to exert control over larger groups, researchers have recommended the group size to be somewhere between four and six participants (Greenbaum, 1988; Vaughn et al., 1996).

Focus groups were specifically conducted to validate the factors identified from the interviews and enable deeper insights into the group's thinking (Sommer and Sommer, 2002). Also, incorporating viewpoints of four different individuals basically helps to verify and increase validity of the data collected.

For the focus groups, the option of tele-conferencing was used to interview a number of individuals at the same time. The proactive approach adopted by the researchers, not only

Konanahalli A et al. (2012) 'International projects and cross-cultural adjustments of British expatriates in Middle East: A qualitative investigation of influencing factors', Australasian Journal of Construction Economics and Building, 12 (3) 31-54 
ensured that the interview was free flowing and in keeping with the topic of discussion, but also assisted in preventing individuals from dominating and ensured that all participants were involved and contributed equally.

\begin{tabular}{|c|c|c|c|c|c|}
\hline $\begin{array}{l}\text { Interview } \\
\text { Code }\end{array}$ & $\begin{array}{l}\text { Assignment } \\
\text { duration in } \\
\text { years }\end{array}$ & $\begin{array}{l}\text { Industry } \\
\text { experience }\end{array}$ & $\begin{array}{l}\text { Job role during } \\
\text { the assignment }\end{array}$ & $\begin{array}{c}\text { Country of } \\
\text { Assignment }\end{array}$ & Profession \\
\hline SA-FG1 & 3 & 6 & Quantity Surveyor & Saudi Arabia & $\begin{array}{l}\text { Engineering } \\
\text { Consultancy }\end{array}$ \\
\hline SA-FG2 & 3 & 7 & Quantity Surveyor & Saudi Arabia & $\begin{array}{l}\text { Engineering } \\
\text { Consultancy }\end{array}$ \\
\hline SA-FG3 & 3 & 25 & $\begin{array}{l}\text { Plants \& } \\
\text { Equipment } \\
\text { Manager }\end{array}$ & Saudi Arabia & $\begin{array}{l}\text { Engineering } \\
\text { Consultancy }\end{array}$ \\
\hline SA-FG4 & 3 & 10 & Planning Manager & Saudi Arabia & $\begin{array}{l}\text { Engineering } \\
\text { Consultancy }\end{array}$ \\
\hline EG-FG1 & Open & 42 & Regional Director & Egypt & Contractor \\
\hline EG-FG2 & 3 & 12 & Project Manager & Egypt & Contractor \\
\hline EG-FG3 & 3 & 25 & $\begin{array}{l}\text { Health \& Safety } \\
\text { Manager }\end{array}$ & Egypt & Contractor \\
\hline EG-FG4 & 3 & 30 & $\begin{array}{l}\text { Commercial } \\
\text { Director }\end{array}$ & Egypt & Contractor \\
\hline QA-FG1 & Open & 35 & Country Manager & Qatar & $\begin{array}{c}\text { Project } \\
\text { Management }\end{array}$ \\
\hline QA-FG2 & Open & 31 & $\begin{array}{l}\text { Regional } \\
\text { Manager }\end{array}$ & Qatar & $\begin{array}{c}\text { Project } \\
\text { Management }\end{array}$ \\
\hline QA-FG3 & 5 & 30 & Strategic Planner & Qatar & $\begin{array}{c}\text { Project } \\
\text { Management }\end{array}$ \\
\hline QA-FG4 & 5 & 9 & Quantity Surveyor & Qatar & $\begin{array}{c}\text { Project } \\
\text { Management }\end{array}$ \\
\hline
\end{tabular}

Table 1 Respondents profile for focus group discussions

According to Fossey, et al., (2002) there is no fixed minimum number of participants recommended to conduct sound qualitative research, however sufficient in depth information needs to be gathered to fully describe the phenomena being studied. Since this study aimed to capture a holistic view of expatriate adjustment, no initial estimate of interviews was considered by the researchers. But after having conducted a total of eight individual interviews and three focus group discussion, the study gathered a large amount of data, where it was possible to identify fully developed general patterns. It reached the point of 'theoretical saturation' where no new insights were being obtained (Glaser and Strauss 1999).

Most of the interviews and focus groups were audio recorded with prior permission. For the one's which permission couldn't be granted, field notes were taken by the researchers. These interviews and focus group discussions lasted somewhere between 1 to 2 hours.

\section{Respondent Profiling}

All the twenty respondents of this study were male. On average, the participants had work experience of 21 years within the industry. Among the interviewed, for $15 \%$ of the participants it was their first overseas posting, $85 \%$ of them were currently working on their international assignment and $60 \%$ of respondents were married. Both focus group discussions and individual interviews included participants from diverse backgrounds ranging from contractors, project management, architectural and engineering fields.

Konanahalli A et al. (2012) 'International projects and cross-cultural adjustments of British expatriates in Middle East: A qualitative investigation of influencing factors', Australasian Journal of Construction Economics and Building, 12 (3) $31-54$ 
All the interviewees were coded. The first two letters in the code refer to the interviewee's country of assignment BA-(Bahrain), SA-(Saudi Arabia), EG-(Egypt), QA-(Qatar), KU(Kuwait), OM-(Oman) and UA-(United Arab Emirates). The next two letters refer to the type of interview i.e. FG-(Focus Group), IN-(Individual interview) and the last number of the code helps to differentiate between each individual. The profiles and details of each interviewee are shown in Table 1 and 2.

\section{Results and Findings of Qualitative Study}

Qualitative data analysis is a systematic and transparent way of making sense and meaning of the data collected (Punch 2005). Each of the interviews was transcribed by carefully listening to audio recording and then translating it into text verbatim. Bogdan \& Biklen, (1992) define qualitative data as "rough materials researchers collect from the world they are studying; they are the particulars that form the basis of analysis". This study analysed the qualitative data using an interpretative approach, also known as a 'descriptive approach'. It provides thorough descriptions and interpretations of social phenomena, including its meaning to those who experience it (Tesch, 1991). This technique helps to structure data extracted from interviews in a rational way to determine factors, actions and reactions. It also presents a holistic view of data rather than a condensed view.

The transcribed data from the individual interviews and focus group discussions were combined with the factors identified from the literature review. The findings of the qualitative study have been listed in Table 3 and discussed in detail in the following section. A list of the findings was sent to each of the participants for approval and validation.

\begin{tabular}{|c|c|c|}
\hline Organisational Factors & Non work Factors & Work Factors \\
\hline $\begin{array}{l}\text { Expatriate selection (Black et al., } \\
\text { 1991; Jassawalla et al.,2004; 25\% } \\
\text { Interviews; } 100 \% \text { Focus groups) }\end{array}$ & $\begin{array}{l}\text { Cultural distance (Black et al., } \\
\text { 1991; Ozorhon et al., 2008; 63\% } \\
\text { Interviews; } 67 \% \text { Focus groups) }\end{array}$ & $\begin{array}{l}\text { Implementing requirements like } \\
\text { quality, (Ozorhon et al., 2007;50 \% } \\
\text { Interviews; 100\% Focus groups) } \\
\text { Health \& Safety (Ozorhon et al., } \\
\text { 2007; Mahalingam \&Levitt, } \\
\text { 2005;25\% Interviews; 33\% Focus } \\
\text { groups) }\end{array}$ \\
\hline $\begin{array}{l}\text { Free choice (Black \& Stephens, } \\
\text { 1989; Feldman, 1988; Wanous, } \\
\text { 1980; Hall, 1976; 38\% Interviews; } \\
\text { 33\% Focus groups) }\end{array}$ & $\begin{array}{l}\text { Political stability (Ozorhon et al., } \\
\text { 2007; Zhi, 1995; Wang et al., } \\
\text { 1999; Ling and Hoang, 2010; } \\
\text { Ofori, 2003; Han \& Diekmann } \\
\text { 2001; 25\% Interviews; 33\% Focus } \\
\text { groups) }\end{array}$ & $\begin{array}{l}\text { Availability of resources (Ozorhon et } \\
\text { al., 2007; Baloi and Price; 2003; } \\
\text { Mahalingam \&Levitt, 2007;63\% } \\
\text { Interviews; 67\% Focus groups) }\end{array}$ \\
\hline $\begin{array}{l}\text { Training Host nationals } \\
\text { (Jassawalla et al.,2004;67\% } \\
\text { Focus groups) }\end{array}$ & $\begin{array}{l}\text { Climatic conditions (Bing, et al., } \\
\text { 1999; Han, et al., 2007; 38\% } \\
\text { Interviews; 67\% Focus groups) }\end{array}$ & $\begin{array}{l}\text { Managing other expatriate groups } \\
\text { (Orrill, 2006; } 50 \% \text { Interviews; 33\% } \\
\text { Focus groups) }\end{array}$ \\
\hline $\begin{array}{l}\text { Cross-cultural training (Black et } \\
\text { al.,1991;Tung,1981) }\end{array}$ & $\begin{array}{l}\text { Presence of expatriate community } \\
\text { (Cohen, } 1977 ; 38 \% \text { interviews; } \\
67 \% \text { Focus groups) }\end{array}$ & $\begin{array}{l}\text { Competence of project parties (Bing } \\
\text { et al., 1999; Ozorhon et al., 2007; } \\
88 \% \text { Interviews; } 67 \% \text { Focus groups) }\end{array}$ \\
\hline $\begin{array}{l}\text { Arranging pre-sojourn visits } \\
\text { (Jassawalla et al.,2004) }\end{array}$ & $\begin{array}{l}\text { Family Adjustment (Black, 1988; } \\
75 \% \text { Interviews; } 67 \% \text { Focus } \\
\text { groups) }\end{array}$ & $\begin{array}{l}\text { Job commitment of locals (63\% } \\
\text { Interviews; } 100 \% \text { Focus groups) }\end{array}$ \\
\hline $\begin{array}{l}\text { Social and logistical support } \\
\text { (Black et al., 1991;Pinder \& } \\
\text { Schroeder, 1987;Tung 1988; } \\
\text { Torbiorn,1982; 88\% Interviews; } \\
\text { 100\% Focus groups) }\end{array}$ & & $\begin{array}{l}\text { Client's understanding of his/her } \\
\text { responsibilities (Baloi \& Price, } \\
\text { 2003; 38\% Interviews; 67\% Focus } \\
\text { groups) }\end{array}$ \\
\hline
\end{tabular}

Konanahalli A et al. (2012) 'International projects and cross-cultural adjustments of British expatriates in Middle East: A qualitative investigation of influencing factors', Australasian Journal of Construction Economics and Building, 12 (3) $31-54$ 


\begin{tabular}{|c|c|c|}
\hline Organisational Factors & Non work Factors & Work Factors \\
\hline $\begin{array}{l}\text { Ongoing head office support } \\
\text { (Aycan, 1997;Black et al., } 1998 \\
\text { 50\% Interviews; } 67 \% \text { Focus } \\
\text { groups) }\end{array}$ & & $\begin{array}{l}\text { Handling contract administration } \\
\text { issues (Hall, 1996; 25\% Interviews; } \\
67 \% \text { Focus groups) }\end{array}$ \\
\hline $\begin{array}{l}\text { Organisational culture novelty } \\
\text { (Church, 1982;Mendenhall \& } \\
\text { Oddou, 1985; Stening,1979) }\end{array}$ & & $\begin{array}{l}\text { Complexity of the project } \\
\text { assignment (Ozorhon et al., 2007; } \\
\text { Han, et al., 2007; 75\% Interviews; } \\
33 \% \text { Focus groups) }\end{array}$ \\
\hline $\begin{array}{l}\text { Mentoring (Volard et al., 1988; } \\
\text { Downes et al. 2002; Mayrhofer } \\
\text { and Scullion, 2002; 25\% } \\
\text { Interviews) }\end{array}$ & & $\begin{array}{l}\text { Flexibility of the client (Ozorhon et } \\
\text { al., } 2007 ; 63 \% \text { Interviews; } 67 \% \\
\text { Focus groups) }\end{array}$ \\
\hline $\begin{array}{l}\text { Job role design (Black et al., } \\
\text { 1991; } 25 \% \text { Interviews; } 67 \% \text { Focus } \\
\text { groups) }\end{array}$ & & $\begin{array}{l}\text { Client's funding capacity (Gunhan } \\
\text { \& Arditi,2005;Bing et al., 1999; } \\
\text { Han, et al., 2007; 50\% Interviews; } \\
67 \% \text { Focus groups) }\end{array}$ \\
\hline $\begin{array}{l}\text { Appointing a local link to deal with } \\
\text { client \& understand local issues } \\
\text { (Chi \& Levitt, 2009; 38\% } \\
\text { Interviews; 33\% Focus groups) }\end{array}$ & & $\begin{array}{l}\text { Introducing new methods, tools and } \\
\text { techniques (25\% Interviews; } 33 \% \\
\text { Focus groups) }\end{array}$ \\
\hline \multirow[t]{9}{*}{$\begin{array}{l}\text { Relocation package (Aycan, 1997; } \\
88 \% \text { Interviews; 100\% Focus } \\
\text { groups) }\end{array}$} & & $\begin{array}{l}\text { Dealing with client representatives } \\
\text { (Han, et al., 2007; 50\% Interviews; } \\
67 \% \text { Focus groups) }\end{array}$ \\
\hline & & $\begin{array}{l}\text { Client's reliability (Baloi and Price; } \\
\text { 2003; 38\% Interviews; 33\% Focus } \\
\text { groups) }\end{array}$ \\
\hline & & $\begin{array}{l}\text { Stakeholders influence on project } \\
\text { assignments (Bing, et al., 1999; } \\
\text { Han, et al., 2007; 38\% Interviews; } \\
67 \% \text { Focus groups) }\end{array}$ \\
\hline & & $\begin{array}{l}\text { Local business culture and work } \\
\text { practices (Javernick-Will and Scott, } \\
\text { 2010; 75\% Interviews; } 100 \% \text { Focus } \\
\text { groups) }\end{array}$ \\
\hline & & $\begin{array}{l}\text { Locals approach to risk } \\
\text { management (Baloi \&Price; 2003; } \\
\text { 25\% Interviews; 33\% Focus groups) }\end{array}$ \\
\hline & & $\begin{array}{l}\text { Relationship between the project } \\
\text { parties (Bing et al., } 1999 ; 50 \% \\
\text { interviews; } 67 \% \text { Focus groups) }\end{array}$ \\
\hline & & $\begin{array}{l}\text { Locals English language skills (Han, } \\
\text { et al., 2007; Bing, et al., 1999;38\% } \\
\text { Interviews; } 67 \% \text { Focus groups) }\end{array}$ \\
\hline & & $\begin{array}{l}\text { Local Bureaucratic Culture (Ling \& } \\
\text { Lim, 2006; 33\% Focus groups) }\end{array}$ \\
\hline & & $\begin{array}{l}\text { Strength of the legal system (Shen, } \\
\text { et al., 2001; Ling and Low, 2007; } \\
\text { Ling and Hoang, 2010; Hall 1996; } \\
67 \% \text { Focus groups) }\end{array}$ \\
\hline
\end{tabular}

Table 2 Factors extracted from Literature Review, Interviews and Focus Groups

\section{Discussion}

Upon completion of the qualtiative data analysis, this research proposes a framework for cross-cultural adjustment, which attempts to cluster factors along organisational, work and non-work issues and assess their impact on the three facets of adjustment. The discussion of the findings is presented by drawing on appropriate quotations from the interviews to clarify and illustrate issues. Narrations or accounts are viewed as story-like constructs that contain individuals' recollections of events (Orbuch 1997). When using narrations, every attempt is made to protect the anonymity of the respondents and their organisation. The

Konanahalli A et al. (2012) 'International projects and cross-cultural adjustments of British expatriates in Middle East: A qualitative investigation of influencing factors', Australasian Journal of Construction Economics and Building, 12 (3) $31-54$ 
extracts are presented such that none of the above mentioned details are revealed. Figure 2 represents the hypothetical framework. Following is the discussion on the aforementioned sub-set variables;

\section{Organisational Support and Expatriate Adjustment}

Organisational support policies and practices are activities, designed by the parent organisation, specifically intended to provide assistance to expatriates working overseas (Galarza, 1999). Construction is a highly cost competitive industry which is also reflected in the expatriate management strategies adopted by the AEC firms. Due to financial costs and other constraints associated with family relocation, organisations have a propensity to select expatriates who are single or newly married. As a result, expatriate selection is merely based on availability and convenience. Most interviews suggested that previous international experience was one of the key criteria driving expatriate selection. EG-FG1 had this to say: -

Generally we don't bring in new people but sometimes we do. New people find it tougher than the one's that have experience. But when it comes to individuals with experience, you know they have managed to succeed before in those situations, you don't think much

To address this gap and prepare individuals for future overseas postings, some larger AEC organisations run graduate programs, where junior staff work alongside senior expatriates on relatively short term assignments.

Another interesting observation made during interviews was the reason why some expatriates were accepting international assignments. Slower economic activities and shrinking workloads in United Kingdom, suggest that expatriates are either under pressure or are left with little choice but to accept the overseas postings, as more and more firms are targeting emerging markets or increasing their established presence in those regions. British expatriates highlighted attractive relocation packages as one of the potential reason behind accepting the assignment. The financial support included tax free salary, bonuses for completing the assignment, living allowances and even relaxation leaves.

This study found significant difference in the amount of support provided by the AEC organisations to the expatriates and their families. Some organisations adopted a strong take-care policy for personnel management. Support included paying utility bills, school fees, rents, setting up contracts for accommodation, medical insurance etc. In some countries they will offer cleaner services, cooks and even laundry facilities for single expats or front line supervisors. SA-FG3 who did not receive much support from his organisation expressed his disappointment over poor HR support: -

Human Resource support did not work very well on this assignment. Initially salaries were not paid on time. Also, work permit visas were not sorted even after eight months of living in the country. It is all down to poor management

Striking cultural differences between Great Britain and Arab regions suggest that AEC organisations could alleviate anxiety by preparing the expatriate and his/her family through cultural training. Additional factors highlighted during the interviews, that need organisational consideration, include: clarity of job roles and responsibilities, placing excessive work demands and mentoring support especially for junior staff. As per the psychological contract theory, organisational support enhances commitment and it eases the stress and uncertainties experienced by the expatriate (Munton and Foster, 1993) whereas violation will result in dissatisfaction and retention problems (Guzzo et al., 1994). Thus, an organisation's support will facilitate all the three aspects of adjustment.

Konanahalli A et al. (2012) 'International projects and cross-cultural adjustments of British expatriates in Middle East: A qualitative investigation of influencing factors', Australasian Journal of Construction Economics and Building, 12 (3) $31-54$ 


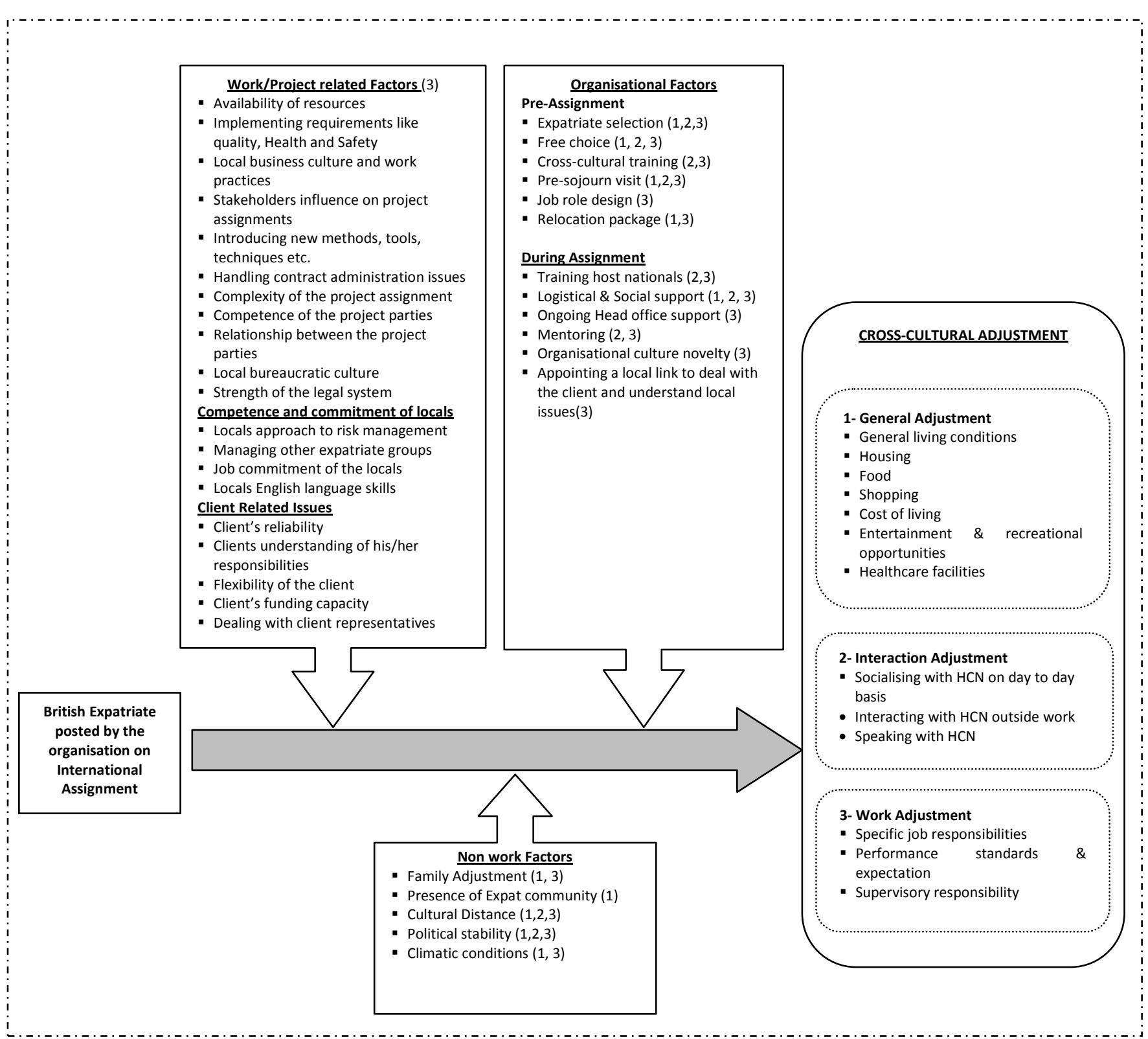

Figure 2 Framework for Cross-cultural Adjustment on International Assignments

(The numbers in the brackets indicate the numbered facet of adjustment to which the variable relates)

\section{Factors particular to the AEC Industry}

The factors particular to the AEC industry are further classified into work-related issues; safety standards; strength of the legal system and bureaucratic culture; job commitment, competence of local staff/workforce and client related issues.

\section{Work Related Factors}

Each country has its distinct way of handling AEC operations, ranging from being either labour to capital intensive (Cunliffe, 1980). Western expatriates posted to work on such assignments need to comprehend that the design standards, systems, tools, techniques and labour skills in some cases can be distinctly different from their home country. Knowledge of the working practises and the business culture of the host nation are important to deliver assignments within the specified parameters. This is specifically relevant to constructors, engineers and designers (Javernick-Will and Scott, 2010).

Konanahalli A et al. (2012) 'International projects and cross-cultural adjustments of British expatriates in Middle East: A qualitative investigation of influencing factors', Australasian Journal of Construction Economics and Building, 12 (3) $31-54$ 
For instance, construction projects in Middle-Eastern countries generally are heavily labour intensive and tend to have limited resources in terms of plant, technology and labour skills with the productivity of workforces varying greatly. Labour skill levels and ability to deliver the finished product were considered to be a challenge and this was echoed in most interviews.

Other factors deducted from the interviews and focus groups were to do with the differences in work practices. For instance, in Middle-Eastern countries it is very common for projects to run beyond the anticipated time and cost parameters. This could be attributed to various reasons such as protracted planning and approval processes, contracts not being taken seriously, unsystematic contractor selection, incompetence of project parties, absence of risk management plans for the projects, interference from government and other project stakeholders, etc. A British Project Manager (UA-IN5) exemplified his experience on contractor selection and their competence: -

Contractors with 4 diggers and 20 men are given multi-million pound contracts to complete in three years. He knows he is going to fail before the start of the job. Also, some contractors secure work outside their domain i.e. contractors good at laying water mains end up putting in sewer mains... without experience they struggle

As a result of these factors it becomes essential to take into account the local conditions and working practices even before preparing the work programs, designs, specifications, etc. If these factors are not taken into account, they could adversely affect the delivery of project assignments.

\section{Safety Standards}

In United Kingdom particular attention has been given to Health and Safety. This is now firmly based within the mainstream British construction industry, but international environments vary drastically on safety standards especially in the developing world. Therefore an issue of great concern when performing overseas projects, for international British contractors, is one of safety standards (Hall, 2000). OM-IN6 highlighted issues with safety standards: -

\section{Normal safety standards are difficult to apply sometimes. We made it a very strong rule to wear hard hats, high visibility jackets and protective clothing. Otherwise they would not do it}

Since Health and Safety continues to be a non-existent concept in some regions, enforcing and implementing these standards takes a lot of effort thereby resulting in considerable delays and additional costs (Mahalingam and Levitt, 2005).

\section{Strength of the Legal System and Bureaucratic Culture}

The environment of the host country has been considered as an element of risk for operating AEC assignments. In particular, the legal system demands special attention because it dictates the management of claims, disputes, conflicts and any issues related to the contract (Ozorhon et al., 2007). An observation by Hall and Jaggar (1996) suggests a scenario which has been echoed in most of the interviews. In the Middle-East the application of the contract clauses could follow an erratic path. An expatriate consultant may find that, when the client fails to keep up with responsibilities, they would tend to put the contract to one side and try fixing a deal. On the other hand, if the fault lies with the consultant, the client would not hesitate to apply the law against him/her to its maximum advantage. Some companies could also end up bargaining (an Arabic practice) and perhaps providing concessions to avoid the application of some of the more onerous clauses.

Konanahalli A et al. (2012) 'International projects and cross-cultural adjustments of British expatriates in Middle East: A qualitative investigation of influencing factors', Australasian Journal of Construction Economics and Building, 12 (3) $31-54$ 
Another aspect of the host nation, highlighted during the interviews, was the bureaucratic culture within the Middle East (i.e. constant interference by the project stakeholders at every project stage).

\section{Job Commitment and Competence of Local Staff / Workforce}

In most cases, it is the local workforce or local staff that actually executes the majority of construction/engineering operations. Interestingly, projects in the Middle East are characterised by participants from diverse cultural backgrounds. The majority of the workforce will come from countries such as, India, Pakistan, Bangladesh, the Philippines, China and Thailand (Enshassi and Bugess, 1991). So, apart from dealing with the locals, the British expatriates will also have to deal with other nationalities with divergent skills, customs and values.

Most expatriates are posted on international operations because there is a lack of expertise in that particular area. To deliver assignments in accordance with international best practice standards requires assistance and support from the local staff, for instance, in situations requiring them to employ new tools and techniques, work longer hours, or even adhere to standard working practices such as health and safety measures, or keeping up with a business culture.

British expatriates being monochronic (i.e. highly structured and having an organised approach to life) have expressed frustration over locals' flexible, relaxed and indirect approach (Loosemore and Muslmani, 1999). A Regional Director (BA-IN4) expressed his opinion of some of his local staff: -

The locals are quite resourceful people, but they have their own ways that are difficult to understand. They do not come to work on time, it is very hard to understand, how can they come to work late daily and think that is not a problem?

English language skills of the locals are advantageous as it eases communication and facilitates greater interaction between them and the expatriates. Due to all these factors, the competence and commitment of local staff/workforce towards work becomes essential as it dictates the successful execution and completion of the assignment, which eventually decides how successful the expatriate has been.

\section{Client related Issues}

In some instances the expatriates have to deal with international clients who can be much more challenging than with UK clients, the fundamental reason being that the expatriate needs to take cultural differences into consideration. These cross-cultural differences often lead to misunderstandings, delays and even conflicts on projects as cited by Muslmani and Loosemore (1999): -

During the process of claim negotiations between the UK national and the Arab clients, tensions could arise between the Arab clients expecting their decisions to be accepted and UK expatriate accustomed to challenging and confrontational culture

To be able to clearly understand the local client's culture, intentions and expectations, British AEC firms need to actively invest in bridging the gaps between the expatriate, who is in charge of the operation and the client. Appointing intermediaries was one strategy used by some British companies, this link includes local bodies aware of the details and the gaps between the two distinct parties who are, at the same time, able to bridge the communication between the two (Chi \& Levitt, 2009).

Other issues highlighted, with regard to clients, were their reliability, funding capacity, flexibility and ability to discharge their part of their responsibilities towards the assignment.

Konanahalli A et al. (2012) 'International projects and cross-cultural adjustments of British expatriates in Middle East: A qualitative investigation of influencing factors', Australasian Journal of Construction Economics and Building, 12 (3) 31-54 
Additionally, Arab clients appoint a local consultant body between them and the international company, which suggests that expatriates/organisations have to deal with another clientele.

All the factors discussed in this section, basically highlight the high job novelty experienced by the British expatriates, suggesting that they have to gain new skills and behaviours to perform overseas. They are specifically related to the AEC projects, distinctive to this industry and potentially exert an influence on adjustment to work and interaction with locals.

\section{Non Work Factors}

Factors listed under this sub-section include: family adjustment, political stability and cultural distance between the home and host countries.

\section{Cultural Distance between UK and Arab countries}

A study conducted by Torbion (1982) suggested that expatriates from the western world struggled with assignments in India, the Middle East, along with Northern and East African countries. Tough living conditions, coupled with poor amenities, harsh climate and divergent cultural differences meant these regions were seen as hardship postings. Arab states, which are predominantly Islamic, have several practices and codes of conduct that contrast with the west. Western expatriates and their families in these locations have to observe caution, for instance alcohol cannot be consumed anywhere except for specially licensed places, there should be abstinence from public displays of affection and dressing should be modest; also homosexuality is completely forbidden. Some British expatriates have expressed their initial cultural shock when they had to deal with a $100 \%$ male environment in their offices and the need to adhere to a dress code for men as well. Also during the holy month of Ramadan the local Muslims observe fasting, so care should be taken to be respectful of these religious times and observances. KU-IN7 had this to say: -

During Ramadan the locals start off early and leave work early, we as expatriates work around these issues and incorporate them within our work routine and avoid scheduling meetings or discussions later in the day

Recent times have seen these oil regions grow dramatically with remarkable improvements to living, healthcare, educational and infrastructure facilities. As a result, a vast majority of the expatriates and their families have expressed their satisfaction with living and working conditions in the Middle-East. Also the presence of large expatriate communities (from all parts of world) was considered to be an added bonus as interaction with locals was limited. As a result, cultural distance potentially affects expats and his/her family's adjustment to the host country.

\section{Political Stability of the Host Country}

Political instability in Middle-Eastern regions due to dictatorships has put serious constraints on the lifestyles of expatriates and their families. Prior awareness of the social and political situations is necessary to be able to make accurate anticipatory adjustments and to develop a realistic picture of the host country. Interviews with British expatriates in the Middle East, suggest that the recent wave of protests which has erupted across Middle Eastern and North African states have considerably put a halt on daily business interactions and general lifestyles of expatriates and their families. In some instances the company had to close operations and request expatriates to return home until life in the region has returned to normalcy.

Therefore, various non-work factors discussed in this section will significantly affect an expatriate's general, interaction and work adjustment. 


\section{Conclusion}

The current study qualitatively explored the influence of organisational, work and non-work factors on the three facets of adjustment of British expatriate's posted on international assignments in the Middle Eastern regions. This study has been able to contribute to knowledge in two ways, firstly by exploring a sample of British expatriates within the AEC sector, and secondly this study has produced a comprehensive framework for expatriate adjustment applicable to British construction professionals in these countries.

Most expatriates and organisations take cross-cultural adjustment for granted, the review however suggests that AEC based assignments in Middle East are composed of highly diverse teams with differing backgrounds, cultures, languages, etc., which creates numerous obstacles for British expatriates. Great Britain is a most individualistic country. In Britain, individual initiative and achievement is stressed, competition is encouraged over cooperation, and individual decision making is valued (Samovar and Porter 2004). So, when British expatriates work on assignments in collectivistic Middle Eastern regions, cultural characteristics and practices of these societies present themselves as major hurdles. For instance, the review suggests that on the work front, most British expatriates could not understand the reasons why locals awarded contracts, promoted their relatives and members of their extended family.

The literature review and exploratory interviews highlight cross-cultural adjustment as one of the biggest challenges facing British expatriates in these regions. In Arab countries one comes across a culture that is vastly different to that of Great Britain. Instances reveal that being unaware of the protocols in the Arab world could have devastating consequences for the expatriate and his/her family. The interviews also established that the current political uprising in Middle East has been a cause of great concern and has seriously affected their movement. Due to its complexity, they need well-rounded support from their employer rather than just targeted support (Takeuchi et al., 2009).

On the work front, AEC assignments in the Middle East are deeply influenced by indigenous business and work practices of the host nation. For instance, striking contrasts exist between British and Arab countries in terms of time keeping, negotiation styles, approaches to conflict, business culture, etc. Since these differences in work culture become apparent in every aspect of the business, in-depth understanding of the local environment is crucial (Kangari and Lucas, 1997). British AEC organisations could address the knowledge gaps and uncertainties associated with international assignments firstly, by employing a comprehensive selection procedure, going beyond technical skills and including factors such as intercultural skills and previous international experience. Offering cultural training prior to departure is also very important. Therefore, organisations should take up this initiative to invest resources and adopt a support policy not only for the expatriate but also for his/her family members. Organisations that take up this initiative of identifying and developing their employees' skills, are generally blessed with loyal and responsible employees (Griffith, 1998; Welch, 2003). This will empower the individual with a clear understanding of international assignment (McCauhey and Bruning, 2005).

Since nothing much can be done to improve the conditions of the host nations, in such circumstances organisational human resource managers must be extra vigilant and offer enough support to the expatriate and his/her family. If the British AEC sector is to reap the benefits of successful expatriation and its associated benefits, it needs to adopt a holistic approach by taking active interest in their staff working overseas. A survey by PriceWaterCoopers (2011) also reiterates that though many engineering and construction companies acknowledge the importance of international mobility and management of their talent, very few have developed a systematic approach to link the two aspects. As highlighted by Hall, (1996) multi-national companies in sectors such as manufacturing,

Konanahalli A et al. (2012) 'International projects and cross-cultural adjustments of British expatriates in Middle East: A qualitative investigation of influencing factors', Australasian Journal of Construction Economics and Building, 12 (3) 31-54 
information technology and the retail Industry have well developed systems along with policy and procedures, inferences could be taken from these evolved sectors and tailored to suit the $A E C$ industry.

\section{Limitations of the Study}

The interpretation of the findings of this study should consider the following limitations. Firstly, the data has been collected from British expatriates working in seven (Qatar, Egypt, Saudi Arabia, United Arab Emirates, Kuwait, Oman and Bahrain) of the twenty Middle Eastern countries. There could be some constraints with regards to the generalizability of our findings for British expatriates working in other Middle Eastern countries. Also, the data has been collected from expatriates living and working in only in large Middle Eastern cities (Doha, Riyadh, Jeddah, Cairo, Kuwait city, Manama, Dubai, Abu Dhabi etc.). The reason for the selection of these locations is that most international $A / E / C$ companies are located in these business cities. Thus, expatriates in remote cities or underdeveloped middle eastern countries may have somewhat different perceptions from expatriates in big and developed cities or countries. Therefore, the findings may not be generalizeable for the whole of Middle East.

The second potential limitation is the representation of the professional backgrounds of the participants, though every attempt was made by the researchers to ensure uniformity. Most of the participants held managerial positions like; regional managers, country managers, project managers, H\&S managers etc. This could be due to the fact that expatriates are sent abroad to fill in high level managerial jobs that demand managing the local work force (Earley and Ang, 2003).

The third limitation of the study is related to the small sample size. Even though there is a sizeable British population working in Middle East, information on AEC expatriates was hard to collect. Also, a substantial portion of this population comprises of self initiated expatriates, who were beyond the scope of this study. Nevertheless, the extensive interviews and focus group discussions did provide a snapshot of the realities of the challenges faced by British expatriates with regards to adjustment in both work and non work situations.

\section{References}

Andreason, A W (2003) 'Expatriate adjustment to foreign assignments', International Journal of Commerce and Management, 13 (1), 42-60

Aycan, Z \& Kanungo, R N (1997) 'Current issues and future challenges in expatriate management', In Aycan, Z. (Ed.), Expatriate Management: Theory and Practice, JAI Press, Greenwich, CT, 117-40

Aycan, Z (1997) 'Expatriate Adjustment as a multifaceted phenomenon: Individual and Organizational level predictors', International Journal of Human Resource Management, 8 (4), 434-56

Babbie, E (2008) The Basics of Social Research, Belmont, CA: Wadsworth

Baloi, D and Price, A (2003) 'Modelling global risk factors affecting construction cost performance', International Journal of Project Management, 21, 261-269

Berry, J W (1992) 'Acculturation and adaptation in a new society', International Migration Quarterly Review, 30, 69-87

Bhaskar-Shrinivas, P. Harrison, D A. Shaffer, M A and Luk, D M (2005) 'Input-based and time based models of international adjustment: meta-analytic evidence and theoretical extensions', Academy of Management Journal, 48 (2), 257-81

Bing, L. Tiong, R L K. Fan, W W and Chew, D A S (1999) 'Risk Management in International Construction Joint Ventures', Journal of Construction Engineering and Management, 125 (4),

Konanahalli A et al. (2012) 'International projects and cross-cultural adjustments of British expatriates in Middle East: A qualitative investigation of influencing factors', Australasian Journal of Construction Economics and Building, 12 (3) $31-54$ 
277-284

Black, J S (1988) 'Work role transitions: a study of American expatriate managers in Japan', Journal of International Business Studies, 19 (2), 277-94

Black, J S and Gregersen, H B (1991) 'Antecedent to cross-cultural adjustment for expatriates in Pacific Rim assignments', Human Relations, 44 (5), 497-515

Black, J S, Mendenhall, M \& Oddou G (1991) 'Toward a comprehensive model of international adjustment: An integration of multiple theoretical perspectives', Academy of Management Review, 16 (2), 291-317

Black, S J \& Stephens, G K (1989) 'The Influence of The Spouse on American Expatriate Adjustment and intent to stay in Pacific Rim overseas Assignments', Journal of Management, 15 (4), 529-44

Bogdan, R C and Biklen, S K (1992) Qualitative research for education: An introduction to theory and methods, (2nd ed.) Boston, MA: Allyn and Bacon

Brewster, C \& Scullion, H (1997) 'A review and an agenda for expatriate HRM', Human Resource Management Journal, 7 (3), 32-41

Caligiuri, P \& Lazarova, P (2002) 'A model for the influence of social interaction and social support on female expatriates' cross-cultural adjustment', International Journal of Human Resource Management, 13 (5), 761-772

Carrillo, P (1994) 'Technology transfer: A survey of international construction companies', Construction Management and Economics, 12 (1), 45-51

Cerdin, J L \& Pargneux, M L (2009) 'Career and international assignment fit: Toward an integrative model of success', Human Resource Managment, 48 (1), 5-25

Chenyi, Q \& Baruch, $Y(2010)$ 'The impact of cross-cultural training for expatriates in a chinese firm', Career Development International, 15 (3), 296 - 318

Chi, C S F and Levitt, R (2009) 'Expatriation Strategies for Project-Based Industries', Proceedings LEAD 2009 Conference

Chua, D K H, Wang, Y, \& Tan, W T (2003) 'Impacts of Obstacles in East Asian Cross Border Construction', Journal of Construction Engineering and Management, 129 (2), 131-41

Church, A (1982) 'Sojourner adjustment', Psychological Bulletin, 91 (3), 540-77

Cohen, E (1977) 'Expatriate Communities', International Sociological Association, Sage Publication, Guilford, 24 (3)

Coyle, W (1992) International Relocation, Oxford, Butterworth-Heinemann

Crosthwaithe, D (1998) 'The internationalization of British construction companies 1990-96:

An empirical analysis', Construction Management and Economics, 16 (4), 389-395

Cunliffe, R (1980) 'Alternative 1- The Lessons from Working Abroad', Architects Journal

Dowling, P. Welch, D and Schuler, R (1998) International Human Resource Management, 3rd Ed, Cincinnati: OH, South-West College Publishing

Downs, M. Thomas, A S \& Singley, R B (2002) 'Predicting Expatriate Job Satisfaction: The Role of Firm Internationalization', Career Development International, 7, 24-36

Dudwick, N. Kuehnast, K. Jones, N V and Woolcock, M (2006) Analyzing Social Capital in Context: A Guide to Using Qualitative Methods and Data

Earley, C P \& Ang, S (2003) Cultural Intelligence: Individuals interactions across cultures, Stanford University Press, Palo Alto

Edstrom, A. \& Galbraith, J R (1977) 'Transfer of Managers as a Coordination and Control Strategy in Multinational Organizations', Administrative Science Quarterly, 22, 248-263

Konanahalli A et al. (2012) 'International projects and cross-cultural adjustments of British expatriates in Middle East: A qualitative investigation of influencing factors', Australasian Journal of Construction Economics and Building, 12 (3) $31-54$ 
Enshassi, A. Burgess, R (1991) 'Managerial Effectiveness and the Style of Management in the Middle East: An Empirical Analysis', Construction Management and Economics, 9 (1), 79-92

Feldman, D C (1988) Managing Careers in Organizations, Scott, Foresman, Glenview, IL.

Fish, A J (2005) 'Assisting cross-border manager adjustment: psycho-cultural and sociocultural interventions', Personnel Review, 34 (2), 225-45

Galarza, L (1999) The relationship between individual, work, organisational, non-work variable and expatriate adjustment- A conceptual and meta-analytical review, Rice University: Unpublished Doctoral dissertation.

Glaser, Barney M and Anselm L Strauss (1999) The Discovery of Grounded Theory: strategies for qualitative research, Hawthorne, NY: Aldine de Gruyter.

Greenbaum, T L (1988) The practical handbook and guide to focus group research, Lexington, MA: Lexington Books

Griffith, C (1994) 'Building a Resilient Workforce', Training, 35, 54-59

Gill, K, Stewart, E, Treasure \& Chadwick (2008) 'Methods of data collection in qualitative research: interviews and focus groups', British Dental Journal, 204 (6), 291-95

GMAC (2008) Global relocation trends survey, Woodridge, IL

Grove, L (1990) 'Burnout among nurses', Nursing Research, 36 (9), 244-55

Gunhan, S and Arditi, D (2005) 'Factors Affecting International Construction', Journal of Construction Engineering and Management, 131, 273

Guzzo, R A. Noonan, K A and Elron, E (1994) 'Expatriate Managers and the Psychological Contract', Journal of Applied Psychology, 79 (4), 617-26

Hall M (2002) 'The cultural dimension as a variable in international construction marketing: a competitive advantage perspective', International Journal of Construction Marketing, 3 (2)

Hall, D T (1976) Careers in Organizations, Goodyear, Pacific Palisades, CA

Hall, M A (2000) International Construction Management - The Cultural Dimension, Unpublished PHD Thesis, Liverpool: Liverpool John Moores University

Hall, M A and Jaggar, D M (1996) 'An examination of the ways in which cultural diversity can affect the business activities of construction consultants operating internationally', In proceedings of RICS COBRA 96 Conference, University of the West of England, Bristol

Han, S H and Diekmann, J E (2001) 'Approaches for Making Risk-Based Go/No-Go Decision for International Projects', Journal of Construction Engineering and Management, 127 (4), 300-308

Han, S H M. Kim, D Y. Kim, H (2007) 'Predicting Profit Performance for Selecting Candidate International Construction Projects', Journal of Construction Engineering and Management, 133 (6), 425-436

Hancock, B (1998) Introduction to qualitative research, Trent focus group

Harvey, M G (1985) 'The executive family: An overlooked variable in international assignment', Columbia Journal of World Business, 20 (1), 84-93

Harzing, A W (1995) 'The Persistent Myth of High Expatriate Failure Rates', International Journal of Human Resource Management, 6, 457-475

Hechanova, R. Beehr, T A \& Christiansen, N D (2003) 'Antecedents and Consequences of Employees' Adjustment To Overseas Assignment', Applied Psychology: An International Review, 15 (2), 213-236

Hoepfl, Marie C (1997) 'Choosing Qualitative Research: A Primer for Technology Education Researchers', Journal of Technology Education, 9 (1)

Konanahalli A et al. (2012) 'International projects and cross-cultural adjustments of British expatriates in Middle East: A qualitative investigation of influencing factors', Australasian Journal of Construction Economics and Building, 12 (3) $31-54$ 
Jassawalla, A. Truglia, C \& Garvey, J (2004) 'Cross-cultural conflict and expatriate manager adjustment; an exploratory study', Management Decision, 42 (7), 837-49

Javernick-Will, A N \& Scott W R (2010) 'Who Needs to Know What? Institutional Knowledge and International Projects', Journal of Construction Engineering and Management, 136 (5), 546-557

Kangari, R and Lucas, C L (1997) Managing international operations, New York, NY: ASCE Press

Kaplan, B and Maxwell, J A (1994), 'Qualitative research methods for evaluating computer information systems', in Anderson, J G, Aydin, C E and Jay, S J (Eds), Evaluating Health Care Information Systems: Methods and Applications, Sage, Thousand Oaks, CA, 45-68

Kim, Y Y and Ruben, B D (1988) 'Intercultural Transformation - A Systems Theory, Kim, Young Yun; Gudykunst, William B.: Theories in Intercultural Communication

Kraimer, L M \& Wayne, J S (2004) 'An expamination of percieved organisational support as a multiple dimensional construct in the context of an expatriate assignment', Journal of Management, 30 (2), 209-37

Kraimer, M L. Wayne, S J \& Jaworski, R A (2001) 'Sources of support and expatriate performance: the mediating role of expatriate adjustment', Personnel Psychology, 54, 71-99

Ling, F and Hoang, V (2010) 'Political, Economic, and Legal Risks Faced in International Projects: Case Study of Vietnam', Journal of Professional Issues in Engineering Education and Practice, 136 (3), 156-164

Ling, F Y Y. Lim, S S Y (2006) 'Cross-cultural encounters when managing projects in China', CCIM2006 Sustainable Development through Culture and Innovation, 26-29 Nov, Dubai, UAE

Ling, Y Y and Low, S P (2007) 'Legal risks faced by foreign architectural, engineering, and construction firms in China', Journal of Professional Issues in Engineering Education and Practice, 133 (30), 238-245

Loosemoore, M and Al Muslmani, A H (1999) 'Construction Project Management in Persian Gulf: Intercultural Communications', International Journal of Project Management, 17 (2), 95-100

Mahalingam, A and Levitt, R E R (2007) 'Institutional Theory as a Framework for Analyzing Conflicts on Global Projects', Journal of Construction Engineering and Management, 133 (7), 517

Mahalingam, A. Levitt, E R (2005) Understanding and mitigating challenges on global projects: The role of the freelance expatriates, Presented at Construction Research Congress

Mayrhofer, W, \& Scullion, H (2002) 'Female Expatriates in International Business: Empirical Evidence from the German Clothing Industry', International journal of Human Resource Management, 13, 815-836

McCaughey, D \& Bruning, N S (2005) 'Enhancing Opportunities for Expatriate Job Satisfaction: Human Resource Strategies for Foreign Assignment Success', Human Resource Planning, 28, 21-29

McEvoy, G and Parker, B (1995) 'Expatriate adjustments: Causes and consequences'. In Selmer, J. (ed). Expatriate Management: New Ideas for International Business, Westport, CT: Quorum Books, 97-114.

Mendenhall, M \& Oddou, G (1985) 'The dimensions of expatriate acculturation: A review', The Academy of Management Review, 10 (1), 39-47

Mendenhall, M. Dunbar, E and Oddou, G (1987) 'Expatriate selection, training and career pathing: a review and critique', Human Resources Management, 26 (3), 331-45

Konanahalli A et al. (2012) 'International projects and cross-cultural adjustments of British expatriates in Middle East: A qualitative investigation of influencing factors', Australasian Journal of Construction Economics and Building, 12 (3) $31-54$ 
Miller, R. \& Lessard, D (2001) 'Understanding and managing risks in large engineering Projects', International Journal of Project Management, 19 (8), 437-43

Morgan, D L (1997) Focus groups as qualitative research (2nd ed.), Thousand Oaks, CA: Sage

Morley, M J \& Flynn, M (2003) 'The relationship between work-role characteristics and intercultural transitional adjustment domain patterns among a sample of US and Canadian expatriates on assignment in Ireland', Cross Cultural Management, 10 (3), 42-57

Munton, A \& Foster, N (1993) Job Relocation: Managing People on the Move, London: Wiley Myers, M D and Avison, D E (2002) 'Overview of qualitative research', in Myers, M D and Avison, D E (Eds), Qualitative Research in Information Systems: A Reader, Sage Publications, London, 1-5

Naumann, E (1993) 'Antecedents and consequences of satisfaction and commitment among expatriate managers', Group and Organization Management, 18, 153-87

Ngowi, B A. Pienaar, E, Talukhaba, J, Mbachu, J (2005) 'The globalization of the construction industry-A review', Building and Environment, 135-141

Nicholson, N (1984) A theory of work role transitions, Administrative Science Quarterly, 29 (2), 172-91

Ofori, G (2003) 'Frameworks for analysing international construction', Construction Management and Economics, 21 (4), 379-391

Ones, D S \& Viswesvaran, C (1997) 'Personality determinants in the prediction of aspects of expatriate job success', In Z. Aycan (ed.), Expatriate Management: Theory and Research, Greenwich, CT: JAI Press

Onwuegbuzie, A J and Leech, N L (2005) 'Taking the "Q" out of research: Teaching research methodology courses without the divide between quantitative and qualitative paradigms', Quality \& Quantity: International Journal of Methodology, 39, 267-296

Onwuegbuzie, Anthony J. Collins, Kathleen M T (2007) 'A Typology of Mixed Methods Sampling Designs in Social Science Research', The Qualitative Report, 12 (2), 281-316

Orbuch, T (1997) 'People accounts count', In Hagen, J., \& Cook, K. S. Eds, Annual review of sociology, 23, 455-478

Orr, R J (2005) Unforeseen Conditions and Costs on Global Projects: Learning to Cope with Unfamiliar Institutions, Embeddedness and Emergent Uncertainty, Stanford University

Orrill, A R (2006) Challenges on culturally diverse construction projects and strategies to overcome them a study of multicultural project management teams in the UAE, Working Paper, Stanford University

Ozorhon B. Arditi, D. Dikmen, I. and Birgonul, M T (2008) 'Implications of Culture in the Performance of International Construction Joint Ventures', Journal of Construction Engineering and Management, 134 (5), 361-370

Ozorhon, B. Arditi, D. Dikmen, I. \& Birgonul, M T (2007) 'Effect of host country and project conditions in international construction joint ventures', International Journal of Project Management, 25, 799-806

Parkinson, E and Morley, M (2006) 'Cross-Cultural Training', In Scullion, H. \& Collings, D.G. (eds.), Global Staffing London, Routledge, 117-138

Peltokorpi, V and Froese, J F (2009) 'Organisational expatriates and self -initiated expatriates: who adjusts better to work and life in Japan', The International journal of Human Resource Management, 20 (5), 1096-1112

Pheng, L S \& Leong, C H Y (2000) 'Cross-cultural project management for international construction in China', International Journal of Project Management, 18 (5), 307-316

Konanahalli A et al. (2012) 'International projects and cross-cultural adjustments of British expatriates in Middle East: A qualitative investigation of influencing factors', Australasian Journal of Construction Economics and Building, 12 (3) $31-54$ 
Pinder, C C and Schroeder, K G (1987) 'Time to proficiency following transfers', Academy of Management Journal, 30, 336-53

Powell R A. Single H M. Lloyd K R (1996) 'Focus groups in mental health research: enhancing the validity of user and provider questionnaires', International Journal of Social Psychology, 42 (3), 193-206

PriceWaterCooper, (2011) Growth reimagined- Engineering \& Construction industry summary, 14th Annual Global CEO Survey

Punch, K (2005) Introduction to social research: Qualitative and Quantitative approaches, Sage Publications

Samovar, A L and Porter, E R (2004) Communication between Cultures, 5th ed. London: Wadsworth Publishing

Selmer, J and Fenner, R C Jr, (2009) 'Spillover effects between work and non-work adjustment among public sector expatriates', Personnel Review, 38 (4), 366 - 79

Selmer, J and Leung, A S M (2003) 'Provision and Adequacy of Corporate Support to Male Expatriates Spouses: An Exploratory Study', Personnel Review, 32, 9-22

Shank, G D (2002) Qualitative Research: A Personal Skills Approach, Upper Saddle River, New Jersey, Pearson Education

Shen, L Y. Wu, W C and Ng, S K (2001) 'Risk assessment for construction joint ventures in China', Journal of Construction Engineering and Management, 127 (1), 76-81

Shenkar, O (2001) 'Cultural Distance Revisited: Towards a More Rigorous Conceptualization and Measurement of Cultural Differences', Journal of International Business Studies, 32 (4), 519-35

Sommer R. Sommer B (2002) A practical guide to behavioural research: tools and techniques, 5th Edition, Oxford University Press, Oxford, UK, 131-135

Sparrow, P. Brewster, C \& Harris, H (2004) Globalizing Human Resource Management, London: Routledge

Stening, G W (1979) 'Problems of cross-cultural contact: a literature review', International Journal of Intercultural Relations, 3, 269-313

Strauss, A. and Corbin, J (1990) Basics of qualitative research: Grounded theory procedures and techniques, Newbury Park, CA: Sage Publications

Stroh, K L \& Caligiuri, M P (1998) 'Strategic human resources: a new source for competitive advantage in the global arena', International Journal of Human Resource Management, 9, 117

Subramaniam, R. Che Rose, R. Kumar, N. Uli, J (2010) 'The effects of Cultural Intelligence on Cross-cultural Adjustment and Job Performance among expatriates in Malaysia', Proceedings of International Conference on Business Economic Research

Takeuchi, R. Wang, M. Marinova, S V \& Yao, X (2009) 'The role of domain-specific perceived organizational support during expatriation and their implications for performance', Organization Science, 20, 621-634

Tesch, R (1991) 'Software for qualitative researchers analysis needs and program capabilities', In Nigel G. Fielding and Raymond M. Lee (eds), Using Computers in Qualitative Research, London: Sage

Torbiorn, I (1982) Living abroad: Personal adjustment and personnel policy in the overseas setting, New York: John Wiley

Tung, R (1982) 'Selection and training procedures of US, European and Japanese multinationals', California Management Review, 25 (1), 57-71

Konanahalli A et al. (2012) 'International projects and cross-cultural adjustments of British expatriates in Middle East: A qualitative investigation of influencing factors', Australasian Journal of Construction Economics and Building, 12 (3) $31-54$ 
Tung, R L \& Miller, E L (1990) 'Managing in the twenty-first century: The need for global orientation', Management International Review, 30, 5-18

Tung, $R \mathrm{~L}$ (1981) 'Selection and training of personnel for overseas assignments', Columbia Journal of World Business, 16 (1), 68-78

Tung, R L (1988) 'Career issues in International Assignments', Academy of management Executive, 2 (3), 241-244

Twum, S (2010) Experiences of unemployed clients with services offered them by the front office of the bridge project, Laurea university of applied sciences, unpublished bachelor's thesis. , Otaniemi

Vance, C M \& Pederon, E S, (1993) 'An ethical argument for host country workforce training and development in the expatriate management assignment', Journal of Business Ethics, 12 (8), 635-43

Vance, C M \& Ring, P S (1994) 'Preparing the Host Country Workforce for Expatriate Managers: The Neglected Other Side of the Coin', Human Resource Development Quarterly, 5, 337- 52

Vaughn, S. Schumm, J S \& Sinagub, J (1996) Focus group interviews in education and psychology, Sage: London

Volard, S V. Francis, D M \& Wagner, E W (1988) 'Underperforming U.S Expatriate Managers: A Study of Problems and Solutions', Practising Manager, 9, 37-40

Wang, S Q. Tiong, R L K. Ting, S K and Ashley, D (1999) 'Political risk: Analysis of key contract clauses in China's BOT project', Journal of Construction Engineering and Management, 125 (3), 190-197

Wanous, J P (1980) Organizational Entry, Addison-Wesley, Reading, MA

Welch, D E (2003) 'Globalisation of Staff Movements: Beyond Cultural Adjustments', Management International Review, 43, 149-69

Yamazaki, Y \& Kayes, D C (2004) 'An experiential approach to cross cultural learning: A review and integration of competencies for successful expatriate adaptation', Academy of management learning and education, 3 (4), 362-379

Zhi, H (1995) 'Risk management for overseas construction projects', International journal of Project Management, 13 (4), 231-237 